\title{
KERUKUNAN ffIDUP ANTAR UMAT BERAGAMA MELALUI SEKEHA TEMPEK DI DESA MEDEWI KECAMATAN PEKUTATAN KABUPATEN JEMBRANA PROPINSI BALI
}

\author{
Oleh : M. Arsyad MG.
}

\section{PENDAHULUAN}

\section{Latar Belakang Masalah}

Satu hal yang menarik bahwa, asal mula dibukanya lahan persawahan dan perkebunan sertapemukiman DesaMedewi, diprakarsai oleh orang-orang Islam. Sejak pemerintahan secara resmi dari tahun 1941 sampai dengan tahun 1945 dikepalai oleh orang Islam.

Ada dua umat yang mendiami wilayah Desa Medewi, di wilayah Desa Adat dihuni oleh mayoritas Umat Hindu, disebagian kecil wilayah Desa (Kelurahan) dinas dihuni oleh minoritas Umat Islam.

Masyarakat adalah suatu satuan kehidupan sosial manusia yang menempati suatu wilayah tertentu, yang keteraturan dalam kehidupan sosial tersebut telah dimungkinkan karena adanya seperangkat pranata-pranata sosial yang telah menjadi tradisi dan kebudayaan yang mereka miliki bersama. (Suparlan, 1982: 82).

Dalam banyak sekali kebudayaan, ada juga anggapan bahwa saat peralihan dari satu tingkat hidup lain, atau dari satu lingkungan sosial ke lingkungan sosial yang lain itu merupakan suatu saat atau peristiwa yang gawat, yang penuh tantangan dan bahaya, baik yang berwujud nyata maupun yang berwujud gaib. Demikian upacaraupacara (di Medewi - Bali) pada masa melampaui saat-saat kerisis serupa itu sering mengandung unsur-unsur yang bermaksud atau bertujuan untuk menolak bahaya yang berwujud gaib tersebutyang diyakini senantiasa mengancam individu serta lingkungannya.

Di dalam hampir semua manusia atau masyarakat di belahan bumi bahkan di seluruh dunia hidup individu yang terbagi oleh adat masyarakatnya ke dalam tingkattingkat tertentu. Tingkat-tingkat sepanjang hidup individu yang di dalam kitab-kitab antropologi sering disebut stages along the life-cycle itu, adalah misalnya dimulai dari masa bayi, masa penyapihan, masa kanakkanak, masa remaja, masa pubertet, masa sudah nikah, masa hamil, sampai kepada masa tua - meninggal atau mati dan sebagainya. Ketika saat-saat peralihan, sewaktu para individu beralih dari satu tingkat hidup ke tingkat lain, biasanya diadakan pesta atau upacara yang merayakan atau memperingati saat peralihan itu. (Koentjaraningrat, $1990: 92$ ).

\section{Tujuan Penelitian}

' Penelitian ini bertujuan untuk mengetahui seperti apa wujud kerukunan hidup umat beragama di Desa Medewi.

Wujud kerukunan hidup umat beragama dalam masyarakat akan dilihat melalui semua rangkaian upacara yang 
menurut sifatnya Suka, dan semua rangkaian upacara yang menurut sifatnya Duka. Dalam konteks Suka (Perkawinan) dan dalam konteks Duka (Kematian) melalui wadah institusi kelembagaan adat (Medewi) Sekeha Tempek atau Sekeha Suka-Duka.

Metodologi Penelitian

Penelitian ini menggunakan disiplin antropologi dengan pendekatan holistik atau secara menyeluruh. Artinya, gejala-gejala yang nampak di seputar masy arakat. Sasaran pengamatan atas gejala-gejala tersebut diperlakukan sebagai unsur-unsur yang satu dengan yang lainnya salin berkaitan secara utuh dan menyeluruh, yang diperlakukan sebagai sebuah kasus.

Penelitian ini dilakukan di Desa Medewi Kecamatan Pekutatan Kabupaten Jembrana Propinsi Bali. Penentuan lokasi ini atas kerja sama antara Badan Penelitian dan Pengembangan (Litbang) Agama dengan Pemerintah Daerah Tingkat I Propinsi Bali, sedang penentuan desa atas kerja sama antara pihak Kantor Departemen Agama Kabupaten Jembrana dengan pihak Pemerintah Daerah Tingkat II Kabupaten Jembrana.

Penelitian ini menggunakan metode observasi terlibat pada rangkaian kegiatan pemujaan-persembahyangan, baik di tempat-tempat suci dan tempat-tempat upacara Umat Hindu, maupun di tempat-tempat suci dan tempat-tempat upacara Umat Islam.

\section{n. MASYARAKAT DAERAH PENE- LITIAN}

Desa Medewi, adalah salah satu dari delapan desa dalam wilayah Kecamatan Pekutatan, Kabupaten Jembrana. Batas desa sebagai berikut : sebelah selatan dengan Samudera Indonesia - sebelah utara dengan Hutan tutupan/Negara - sebelah timur Sungai Medewi/Desa Pulukan - sebelah barat dengan Sungai Yeh Satang/Desa Yeh Sumbul.

Jarak dari Gilimanuk $56 \mathrm{Km}$. Jarak dari Denpasar $76 \mathrm{Km}$, sedang jarak dari air port Ngurah Rai $100 \mathrm{Km}$. Transportasi umum adalah Bus dan Ojek Sepeda Motor. Luas wilayah 2.561.000 $\mathrm{Ha}$, terdiri dari dataran rendah dan perbukitan membujur utara-selatan dengan ketinggian antara 0 - $450 \mathrm{~m}$. dari permukaan laut.

Ada tiga tahapan orang-orang datang ke wilayah ini; pertama, pada tahun 1874 orang-orang Islam yang berasal dari Desa Air Kuning Negara; kedua, pada tahun 1890 orang-orang Islam yang berasal dari Desa Loloan Negara; ketiga, pada tahun 1912 orang-orang Hindu dari Desa Dauh Tukad Kecamatan Mendoyo.

Kata "Medewi" berasal dari kata Meduwi yang berarti duri, kemudian setelah mengalami perkembangan menjadi suatu ungkapan yang menyeluruh dan disenangi oleh penduduk menjadi Medewi.

Satu informasi penting bahwa, sejak resminya Medewi pada tahun 1941 sebagai pemerintahan desatersendiri, dengan kepala desa pertama adalah dari golongan Umat Islam bernama Saleh, sampai dengan tahun 1945. Kini sudah kepala desa yang ketujuh, berarti enam orang sesudah orang pertama sebagaimana tersebut di atas dikepalai oleh golongan Umat Hindu.

Organisasi atau lembaga kemasyarakatan seperti LKMD LMD-PKK-Karang Taruna, kecuali lembaga adat, semuanya 
terdapat dari kedua unsur golongan umat baik yang mayoritas Umat Hindu, maupun yang minoritas Umat Islam.

Jumlah penduduk sebanyak 3.516 jiwa, terdiri dari: Umat Hindu laki-laki 998 jiwa (28\%) perempuan 1.077 jiwa (31\%) total 2.075) jiwa (59\%); Umat Islam laki-laki 700 jiwa (20\%) perempuan 741 jiwa (21\%) total 1.441 jiwa (41\%).

Kategorisasi mata pencaharian pokok: petani/peternak 1.112 jiwa $(31,62 \%)$; jasa (termasuk pegawai) 233 jiwa $(6,65 \%)$; nelayan 150 jiwa (4.26\%); pedagang 23 jiwa $(0,65 \%)$; total 1.518 jiwa $(43,17 \%)$, selebihnya sebesar $56,83 \%$ adalah anak-anak dan orang tua yang tidak atau belum mempunyai mata pencaharian pokok, dengan kata lain ditanggung oleh orang tuanya atau anaknya.

Tingkat pendidikan : yang belum sekolah 1.253 jiwa; dudukdi T.K. 32 jiwa; duduk di S.D. 738 jiwa; tidak tamat SD (drop out) 643 jiwa; tamat SD tidak melanjutkan 638 jiwa; duduk di SMTP 136 jiwa; tamat SMTP tidak melanjutkan 66 jiwa; duduk di SMTA 99 jiwa; tamat SMTA tidak melanjutkan 24 jiwa; duduk di perguruan tinggi 70 jiwa; sarjana muda 14 jiwa; dan sarjana 13 jiwa.

Rata-rata kelahiran pertahun 1,63\%, rata-rata kematian pertahun $0,70 \%$ pertahun. (Sumber data dari Kantor Desa Medewi, 1992).

\section{SEKEHA TEMPEK}

Undaan prajuru adat desa adat Medewi, menunjukkan bahwa Kelihan Tempek/ Kasinoman yang merupakan ujung tombak Bendesa adat dalam melayani kepentingan sehari-hari anggota masyarakat yang disebut krama adat dalam wilayah tertentu.

Sekeha artinya suatu institusi/lembaga adat, sedang Tempek artinya nama dari suatu institusi/lembaga adat. Biasanya kata "SekehaTempek" diikuti dengan kata "nama lokasi dimana institusi/lembaga adat itu melakukan aktivitas"; misalnya: tempek kangin, tempek kauh atau tempek kaja, dan tempek kelod. (Majelis Pembina Lembaga Adat Daerah Tingkat I Bali, 1990:28).

Ke wajiban yang paling menonjol dalam kehidupan krama banjar, adalah melaksanakan gotong-royong dalam persekutuan hidup bersama, baik dalam keadaan Suka maupun dalam keadaan Duka. (Ibid, h.35).

Suatu kenyataan di lapangan bahwa, penamaan dari sebagian "besar penduduk akan sebutan "Tempek" atau "Kasinoma", juga sering disebut "Suka-Duka". Jadi Sekeha Suka Duka Banjar Dlod Setra misalnya, adalah salah satu institusi atau kelompok sosial kemasyarakatan yang melayani kebutuhan para krama adat dalam kegiatan upacara perkawinan dalam konteks Suka, dan dalam kegiatan upacara kematian dalam konteks Duka.

Sekeha Tempek ini, berfungsi dan melakukan pelayanan kepada masyarakatnya dalam konteks Suka dan Duka seperti yang dikatakan oleh Koentjara' ningkrat along the life-cycle. Dalam disiplin ilmu antropologi, memang upacara-upacara serupa itu disebut cirisis-rites atau upacara waktu krisis, atau rites de passege atau upacara peralihan. (Koentjaraningrat, $1990: 93)$.

Sehubungan dengan apa yang telah diungkapkan oleh Koentjaraningrat terse- 
but di atas, maka penulis dalam pelataran ini mengungkapkan apa-apa yang merupakan temuan baru dalam raengikuti aktivitas lembaga adat tersebut.

Dalam kegiatan-kegiatan seperti tersebut di atas, peneliti secara bersama dengan institusi adat yang disebut "Sekeha Tempek". Setiap ada informasi melalui pengumuman ketua yang disebut kelihan, yang segera dimulai dengan seruan berbunyinya gentongan adat yang terbuat dari kayu khusus yang pajang secara tergantung di atas menara yang tinggi di Bale Banjar atau di tempat kediaman seorang kelihan, yang disebut oleh banyak orang dengan nama "kul-kul".

Pada kenyataannya, institusi ini berperan aktif baik dalam konteks Suka (perkawinan) maupun dalam konteks Duka (kematian).

Ketika merakit suatu bangunan darurat yang disebut dalam sebutan lokal "Salon", untuk tempat berteduh dan berkumpul penduduk yang berdatangan. Demikian juga ketika merakit wadah sesajen yang disebut "banten". Demikian juga dalam mempersiapkan konsumsi beserta peralatan yang mendukung terlaksananya upacara dengan baik, secara swadaya model gotong-royong dilakukan oleh keterli batan banyak orang. Sebagian besar dari resiko yang diakibatkan oleh suatu upacara, menjaditanggungjawab mutlak bagi krama adat, sebagaimana yang telah disepakati secara bersama yang disebut "rembug adat".

Rembug adat ini dituangkan dalam nilai atau norma yang disebut "awig-awig". Awig-awig ini secara mutlak mesti di- lakukan oleh setiap krama adat, karena mempunyai sangsi dari kewajiban yang rotinutas tersebut. Dalam pelataran semacam tersebut, tidak berarti mengurangi kewajiban dan tanggung jawab keluarga yang melakukan upacara. Hal itu seputar persamaannya, adapun perbedaannya adalah: biasanya pesta/upacara Suka itu sebagaimana layaknya, relatif menggunakan waktu yang tidak lama, sedang pesta/upa cara Duka itu minimal sepekan lamanya. Waktu sepekan itu adalah untuk melakukan persiapan dalam rangka ngaben atau mapendam atas Orang yang mati, sampai pada upacara terakhir setelah arwah dipanggil dari arah laut, kembali bersama pada tempat yang telah disiapkan di halaman rumah orang yang mati tersebut (rumah duka).

Pada moment-moment seperti yang tersebut di atas itu, tidak tertutup hadirnya streotip dan prasangka buruk maupun prasangka baik, baik itu dari orang lain, dari interen golongan Umat Hindu sendiri maupun dari eksteren golongan Umat Hindu.

Ada moment yang sangat menarik, yang dilakukan oleh institusi adat tersebut, yakni : pada konteks upacara Suka (perkawinan) mereka menyiapkan waktu khusus untuk menjamu tetamunya yang beragama Islam (non Hindu). Mulai dari penyediaan bahan baku sampai diproses dan siap dikonsumsi dan dilayani oleh petugas yang telah dipersiapkan semuanya dilakukan oleh orangorang Islam, pokoknya ada jaminan layak atau halal; sedang pada konteks upacara Duka (kematian) orang-orang non Hindu (Islam) hanya melayat orang mati di rumah duka, tidak sampai mengantar kekuburan (setra istilah lokal Hindu Bali). 


\section{KERUKUNAN HIDUP ANTAR UMAT BERAGAMA}

Pada konteks kerukunan hidup antar Umat Beragama yakni dari golongan beragama Hindu sebagai golongan mayoritas dan dari golongan minoritas beragama Islam. Umat Hindu sebanyak 59\%, sedang Umat Islam sebanyak $41 \%$. Pada pelataran ini penulis/peneliti tidak akan menonjolkan streotip dan prasangka atau dengan kata lain konflik. Sebagaimana dikatakan bah wa, konflik didefinisikan sebagai pertentangan yang bersifat langsung dan disadari antara individu-individu atau kelompok-kelompok untuk mencapai tujuan yang sama. (Drs. Achmad Fedyani Saifuddin, M.A., : 7). Baik itu adanya di kalangan interen maupun antar pemeluk agama yang ada di lokasi penelitian, akan tetapi kajian difokuskan pada kedua kasus sebagaimana yang diangkat kepermukaan terdahulu, yaitu dua moment yang sangat menarik dalam konteks Suka (perkawinan) dan dalam konteks Duka (kematian) melalui aktivitas institusi Sekeha Tempek tersebut. Kajian ini dilakukan kasus perkasus.

Pertama, pada pelataran Suka dengan konteks upacara perkawinan dari golongan Umat Hindu dari pelapisan darah Satria mempelai suami dengan dari pelapisan darah Sudra mempelai isteri. Hal ini kalau nantinya "Ida Sang Hyang Widhi" atau Tuhan Yang MahaEsa mengurniai keturunan anak, maka anaknya itu mengikuti garis keturunan bapak, yang biasanya disebut patrilineal, berarti anaknya nantinya berhak menggunakan predikat nama "gusti", seperti penamaan bagi orang-orang pelapisan darah satria lainnya. Hal ini telah menjadi kenyataan pada kebanyakan orang-orang semacam itu di lokasi penelitian.

Pola atau corak kerukunan interen Umat Hindu, yang nampak pada kontek itu adalah : ketika seminggu sebelum pelaksanaan puncak acara perkawinan tersebut di atas, institusi/lembaga adat yang disebut "Sekeha Tempek" atau "Sekeha Suka-Duka" melalui kelihan atau ketuanya, mengumpulkan tenaga atau krama adat banjar Dlod Setra, dengan masing-masing orang membawa dua lembar atap.

Bagi mereka yang tidak berkesempatan membawa atap nipa, maka boleh membawa sebatang bambu sebagai joing dua orang krama, artinya sebatang bambu dapat memenuhi kewajiban dari dua orang.

Fungsi atap nipa dapat juga digantikan oleh berfungsinya bambu, karena bahan baku atap nipa dan bambu, nantinya dirakit secara gotong-royong oleh kebanyakan krama menjadi sebuah atau lebih dari sebuah bangunan darurat, yang berfungsi sebagai tempat berteduh atau duduk para orang-orang atau tetamu yang nantinya hadir pada upacara tersebut, yang disebut "Salon" (istilah lokal).

Kegunaan salon tersebut, selain berfungsi seperti yang tersebut di atas, masih banyak fungsi lainnya, yang dapat dimanr faatkan berbagai keperluan upacara seperti untuk : dapur, tempat banten, sajen dan sebagainya.

Hal tersebut biasanya dilakukan pada waktu dini hari, sebelum para krama turun sawah - ke ladang - ke kantor - ataupun ke sekolah-ataukah ke pasar.

No. 10 Th. V Januari / Juni 1994 
Kegiatan semacam ini dipimpin langsung oleh kelihan pada tiap tahapan kerja. Ketika kegiatan semacam ini berlangsung, maka dari pihak man rumah menyuguhkan jajan kue-kue dengan ciri khas menyuguhkan minuman kopi yang berisi setengah/separuh dari kapasitas gelas, serta maka nan/sarapan pagi buat para krama yang hadir bergotong-royong. Gotongroyong semacam ini berlangsung antara satu sampai dua jam lamanya pada setiap kegiatan Tempek.

Ketika akan istirahat atau usai, kelihan berdiri untuk menginformasikan kegiatan apa lagi yang nantinya akan dilakukan pada waktu berikutnya.

Kenyataannya kasus tersebut di atas, sejak dari saat berdirinya "salon" di pagi hari sampai pada hari puncak acara, para krama dan kerabat serta tetangga di tempat itu memperlihatkan kegiatan yang berlangsung terus-menerus, dalam artian silih berganti. Ada yang membuat wadah banten yang disebut "Kelekat" (istilah lokal), ada yang membuat kue-kue, ada yang menghias/mendekor ruangan dan salon atau bangunan dari janur kelapa dan bungabungaan, dari tumbuh-tumbuhan. Kegiatan tersebut tanpa diperlukan suatu perjanjian atau kesepakatan honor atau jasa sebelumnya, nampaknya kegiatan tersebut berlangsung secara gotong-royong.

Hal ini merupakan suatu jawaban dari pertanyaan yang dikatakan bahwa, mengapa para krama tersebut rela membuang waktunya, barang satu sampai dua jam, pada setiap kegiatan Sekeha Tempek. Tidak lain bahwa, ada norma atau nilai yang disepakati bersama oleh krama adat yang mengelompokkan diri dalam institusi Sekeha Tempek sebagaimana yang ada di Sekeha Tempek Dlod Setra. Hal itu dituangkan secara tertulis sebagai aturan yang disebut "awig-awig" (istilah Bali), yang berisikan hak dan kewajiban serta sangsi.

Demikianlah pola atau corakkerukunan hidup interen Umat Hindu yang ada di lokasi penelitian tersebut.

Pola atau corak kerukunan antar umat beragama dengan kata lain kerukunan antar Umat Hindu dari Golongan mayoritas dengan Umat Islam dari Golongan minoritas. Yang nampak dalam kontek itu adalah : secara keluarga dan kerabat dan tetangga telah disepakati untuk melakukan secara khusus, mengundang dan menjamu orangorang dari golongan minoritas Umat Islam untuk makan siang.

Orang yang dipercayai dan diserahi bertanggung jawab tentang pengelolaan beserta perlengkapannya, adalah tetangga yang Muslim bernama Mas, dari bidang pangan pokj a PKK yang memiliki ketrampilan tata boga atau masak memasak, dan pemilik warung tempat langganan dari keluarga dan kerabat pihak tuan rumah.

Orang-orang yang diundang dari golongan minoritas tersebut sebany ak dua puluh satu Orang Muslim dan Muslimat, dengan latar belakang status pertemanan - sejawat - tetangga termasuk relasi dan nasabah. Kehadiran golongan minoritas Umat Islam tersebut, ada yang membawa kado yang berisi barang pecah-belah kebutuhan rumah tangga, dan ada pula yang menyerahkan amplop tertutup yang berisi antara seribu lima ratus rupiah sampai dengan lima ribu rupiah. 
Seusai makan siang, antara tuan rumah beserta mempelai temanten pria-wanita dari Golongan Mayoritas Hindu, berjabatan tangan sambil tertawa dan bercanda ada yang menggunakan bahasa Bali, ada juga yang menggunakan bahasa Nasional yakni bahasa Indonesia sambil melontarkan senyum kedamaian.

Babakan berikutnya adalah acara interen Umat Hindu yang kembali ditangani oleh institusi Sekeha Tempak. Macam upacara atau raganan apakah lagi yang akan dilakukan selanjutnya, penulis tidak mengungkapkan lagi, karena hal itu menyangkut pada pelataran upacara sakral atau ritual keagamaan.

Demikianlah pola atau corak kerukunan antar umat beragama yang nampak antara Golongan Mayoritas Umat Hindu dengan Golongan Minoritas Umat Islam pada kontek upacara Suka - Perkawinan pada pelataran upacara serimonial, tidak sampai pada pelataran upacara ritual keagamaan.

Kedua, pada pelataran Duka dengan konteks upacara kematian anak pertama yang berusia sepuluh hari, dari Golongan Mayoritas Umat Hindu yang dari pelapisan darah Sudra, pasangan suami-isteri KS dan KSI, yang meninggal pada hari Sabtu 24 Oktober 1992 pada jam 14.00 wita di banjar Dlod Setra.

Ketika itu keluarga - dan tetangga serta kerabat, berdatangan untuk melayat, dan selanjutnya ada yang turut mengantar ke kuburan yang disebut "Setra" (istilah Bali), untuk selanjutnya dikuburkan atau ditanam yang disebut "Dipendem" (istilah Bali). Sebagian besar yang hadir adalah dari Golongan Mayoritas Umat Hindu, yang terdiri dari keluarga - kerabat - dan krama adat, orang-orang inilah yang melayat dan mengantar sampai ke Setra. Sebagian kecil yang hadir adalah dari Golongan Minoritas Umat Islam, yang terdiri dari teman - tetangga yang bernama SUR dan MAS yang hanya melayat di rumah duka saja, tidk sampai mengantar ke Setra.

Mengapa hal itu bisa terjadi. Pertanyaan itu terjawab dengan suatu kenyataan bahwa, di antara Golongan Minoritas dan Moyoritas karena ada hubungan pertemanan sejak kecil - sekolah - dan satu tempat kost di Jembrana, dan sampai sekarang masih tetangga dekat. Mereka dalam berhubungan tidak saling menampakkan corak dan identitas keagamaannya.

Umat Islam yang menyempatkan diri untuk datang melayat ketika itu, sekaligus merupakan perwujudan interaksi sosial Antar Umat Beragama. Menurut anggapan sementara dari sebagian besar Golongan Minoritas tentang upacara yang dilakukan di Setra, adalah merupakan upacara ritual keagamaan, dengan kata lain menyangkut masalah teknis agama Hindu, maka dari itu, kalau dari Golongan Umat Islam hadir hanya sampai pada di rumah duka saja, karena tidak semua acara teknis/ritual ada juga acara seremonialnya.

Sarana pendukung untuk pelestarian hidup umat beragama, tersedia sarana: untuk Golongan Mayoritas Umat Hindu seperti : TRI KAHYANGAN : Pura Pusa - Pura Desa - dan Pura Dalem - Pura Kawitan Pura Bedugul - Dadia - Merajan - dan Kemulan; untuk Golongan Minoritas Umat Islam seperti : Mesjid Al-Akmal - Baitul Ibadah - Nurul Akmal dan Baitul Amin. 
Institusi gotong-royong yang dimiliki oleh Golongan Mayoritas Umat Hindu disebut Sekeha Tempek, sedang institusi gotongroyong yang dimiliki oleh Golongan Minoritas Umat Islam disebut Rukun Kifayah yang disingkat RKA.

\section{KESIMPULAN}

Dari kajian kasus perkasus sebagaimanayang diangkatpadauraian tersebut di atas, maka dapat disimpulkan bahwa : Kasus pertama, menunjukkan bahwa melalui institusi adat Sekeha Tempek Dlod Setratelah melakukan suatu aktivitas dalam kontek upacara Suka - Perkawinan seagama, dalam hal ini Hindu. Di antara upacara perkawinan itu disiapkan waktu khusus untuk memberi kesempatan bagi Umat yang Minoritas lokal (Islam), dapat menampakkan rasa solidaritas Nasionalnya melalui pola interaksi sosial ekonomi dalam corak hubungan saling menguntungkan, pada kontek upacara seremonial tidak pada kontek upacara sakral/ritual keagamaan. Kasus kedua, menunjukkan bahwa melalui institusi adat Sekeha Tempek Dlod Setra telah melakukan suatu aktivitas dalam kontek upacara kematian orang Hindu. Di antara serangkaian upacara duka - kematian tersebut tetap membuka pintu untuk memberi kesempatan bagi Umat yang Minoritas lokal (Islam), dapat menampakkan rasa Pancasilais dan solidaritas Nasionalnyamelalui pola interaksi sosial ekonomi - pertemanan dan ketetanggaan, pada kontek upacara seremonial tidak pada kontek upacara sakral/ ritual keagamaan.

Peningkatan kualitas pemahaman keagamaan pada sisi pengetahuan keagamaan, perlu wawasan kebangsaan yang lebih meluas. Dalam hal ini perlunya lebih diintensipkan penyuluhan agama, baik bagi Umat Hindu sebagai Umat yang Mayoritas lokal, maupun bagi Umat Islam sebagai Umat yang Minoritas lokal, termasuk informasi kerukunan yang dibutuhkan oleh wahana kebangsaan yang Pancasilais, yang saling menghargai antara satu dengan lainnya, bersatu dan rukun dalam perbedaan. 


\section{DAFTAR BACAAN}

Achmad Fedyani Saifuddin, Drs, MA. -

1986 Konflik dan Integrasi, Perbedaan dalam agama Islam, CV. Rajawali, Jakarta.

Badan Litbang Agama Depag RI, - Pedo1989/1990 man Pembinaan Kerukunan Hidup Beragama, Proyek Pembinaan Kerukunan Hidup Beragama, Jakarta.

Barth, Fredrik, Kelompok Etnik dan 1998 Batasannya, diterjemahkan oleh Nining I Soesilo, Universitas Indonesia UI Press, Jakarta.

Cudamani, Bagaimana Umat Hindu 1991 Menghayati Ida Sanghiyang Widhi, (Tuhan Yang Maha Esa), Hanoman Sakti, Jakarta

Koentjaraningrat, Beberapa Pokok Antropologi Sosial, Dian Rakyat, 1990 Jakarta.
Suparlan, Parsudi, Pengetahuan Budaya, I9gl Ilmu-IImu Sosial dan Pengkajian MasalahMasalah Agama, Badan Litbang Departemen Agama RI, Jakarta.

1986 Dalam Individu, Keluarga dan Masyarakat, Akademika Pressindo, Jakarta.

1988 Agama Dalam Analisa dan interpretasi Sosiologi, Rajawali, Jakarta.

Syafi'i, Ahmad Rangkuman penelitian Konfigurasi Transformasi Kehidupan Agama, Menjelang Tinggal Landas Pembangunan Nasional (Tahap Pertama), Badan Litbang Agama RI, Jakarta.

Majelis Pembina Lembaga Mengenal Dan Pembinaan Desa Adat Di Bali, Proyek Pemantapan Lembaga

1989/1990 Adatterbesar di 8 (delapan) Kabupaten dati It. 